DOI: $10.21554 / \mathrm{hrr} .091907$

\title{
INTERESTS OF DEAF AND HARD-OF-HEARING STUDENTS FOR SPORTS
}

\author{
Meliha Povlakić Hadžiefendić ${ }^{1}$ \\ Esad H. Mahmutović
}

\section{Original scientific paper}

Center for Hearing and Speech Rehabilitation, Sarajevo, Bosnia and Herzegovina

Center for Education and Rehabilitation of hearing and speaking Tuzla, Bosnia and Herzegovina

Received: $2019 / 7 / 8$

Accepted: 2019/9/9

\begin{abstract}
Slow speech-language development and reduced communication skills can affect weaker experiences in different activities. The aim of the research was to determine interests and aspirations for sports of deaf and hard-of-hearing students. The sample consisted of 94 examinees, divided into two groups. The first group consisted of 47 deaf and hard-of-hearing students, and the second, control group, the same number of their hearing peers, both sexes, average age of $16 \pm 1.27$ years. The test used for research was Test for Interests and Aspirations of Students of 20 Assertions - Indicators of attitudes about participation and opportunities provided by eight different activities, of which sport is one of them. The obtained data were processed with descriptive analysis, and the differences between the groups tested with the t-test. Deaf and hard-of-hearing students recognize the importance of dealing with sports, but feel that they do not participate enough. The examinees without hearing impairments pleaded more favorably about participation in sport activities than examinees with hearing impairment, and the statistically significant difference was established. Statistically significant difference was not determined in the case of pleading about the possibilities provided by sport. Deaf and hard-of-hearing students believe that sport can have significant impact on better socialization, wherefore it is necessary to include these persons in sport activities at an early age.
\end{abstract}

Keywords: deaf, hard-of-hearing, sport

\section{INTRODUCTION}

Hearing impairment as a form of sensory impairment can cause various negative consequences for the development of the child. The consequences are more severe if the damage occurred in the period before the formation of speech and language, which can result in deviations in the communication, emotional, cognitive and social development of the child.

People who suffer from hearing loss have limited capabilities to interact with their surroundings and have communication problems with friends and family (Becker, Flower, Glass, \& Newcomer, 1984; see Olaosun \& Ogundiran, 2013). Perceptual hearing impairments have a major impact on the development of a personality that is primarily reflected in the adoption of language and speech, but there are many other problems, such as the problem of communicating with the environment, which leaves a significant influence on the emotional and social empowerment of people with hearing impairment (Hasanbegović \& Sinanović, 2008).

\section{${ }^{1}$ Correspodence to:}

Meliha Povlakić Hadžiefendić, Center for Hearing and Speech Rehabilitation, Sarajevo, Bosnia and Herzegovina

Asima Ferhatovića 2, Sarajevo 71000, Bosnia and Herzegovina

Phone:+387 61635290

E-mail: melihapovlakicotmail.com 
Severe hearing impairments cause major communication problems and cause more severe consequences in the development of cognitive functions, social and emotional functioning of deaf people. Unlike them, minor hearing damage does not cause major problems in cognitive functioning, and the consequences are more pronounced on a socially emotional plan (Radoman, 2003).

Difficulties with both educational and psycho-social progress, along with problems with speech understanding may also occur with those children who suffer from mild or unilateral permanent hearing loss (Bess et al., 1988; Culbertson \& Gilbert 1996; see Shemesh, 2010).

Pshychosocial health is another important thing related to the subject of hearing impairment. Deafness in childhood causes problems with social and psycho-intellectual development because of the children's inability to fully interact with their environment (Davidson, Hyde, \& Alberti 1989; see Rajendran, Roy, \& Jeevanantham, 2012). Those who suffer from hearing loss have limited social development due to the social and cultural factors that differ between the hearing and deaf children (Riungu, 2002; Martin \& Bat-Chava, 2003, see Zipporah, 2016). Because of the differences in social spheres, deaf children often have the feeling of loneliness and alienation from the society (Martin \& Bat-Chava, 2003; Riungu, 2002; Scheetz, 2004; see Zipporah, 2016).

Reports claim that people who suffer from hearing loss refrain from taking part in social activities, have poorer social relations and more frequent mood disorders, which leads to an increase in psychological stress (Hogan, 2009; see Rajendran et al., 2012).

The importance the use of certain sports activities has an impact on cognitive abilities, increased attention, selfconfidence, concentration, development of values, attitudes and habits, independence and socialization.

„Sport can bring deaf people together in a setting where they are not isolated by communication barriers or seen as being different or abnormal because of an inability to hear. By providing deaf people with a means by which their social and psychological needs are fulfilled - in a way which is absent from their daily lives amongst a hearing majority who do not fully understand them, or with whom communication is at best limited - deaf sport can provide the emotional rewards that Holt contends derive from participation in sport" (Atherton, Turner, \& Russell, 2001, p. 31).

Sport can be considered a means for interaction and understanding for a Deaf participant,it gives Deaf people a social identification that cannot be achieved through other ways of socio-cultural practises (Arsic, et al., 2012; see Johnson, 2014).
Stewart (1991; see Arsic, Stankovic, \& Zrnzevic, 2015) defines the sport among deaf in three dimensions and spheres: the social, psychological and educational. The socialization of the deaf and their inclusion in the community represents the most important goal for each deaf individual. Stewart further cites that "...the nature of sport among the deaf population is to promote the interaction between the deaf individuals".

Children with hearing impairment may be less involved in sports due to deferred communication skills and emphasis on hearing and speech rehabilitation exercises.

Because of the equal playing field where both hearing and deaf people can cooperate, sport is considered as a convenient channel for socialization of deaf people. Since the communication is not a significant barrier, deaf people do not experience threatening atmosphere and can have meaningful social interactions (Stewart, 1991; see Dummer, Haubenstricker, \& Stewart, 1996). For many Deaf individuals, participation in a specific Deaf sport or joining a sports club is a major means of socialization (Stewart \& Ellis, 2005; see Johnson, 2014).

„Problems of low self-esteem, inadequate education and job opportunities, discrimination and negative perception, and an inability to have effective communication with the hearing majority are all difficulties that can be put aside whilst involved in deaf sport" (Atherton, Turner, \& Russell, 2001, p. 31).

When people who suffer from hearing impairment participate in sports, usually it is an excellent opportunity for the eventual development of a healthier lifestyle. It is the task of the society to include people with hearing impairment in various recreation and sport activities (Stewart \& Ellis 2005; see Karademir, 2015).

„Sport among the deaf population also encourages psychological health in such a way that they identify them selves based on group membership and thus gain access into systems of social support. In addition, sport among the deaf population also has an educational component and a value which manifests in the fact that deaf individuals together learn through sports activities and work towards a goal in communion" (Arsic, Stankovic, \& Zrnzevic, 2015, p. 43). When parents and school promote children's participation in sporting activities, it positively influences their physical development, which is very important during school years because it help children develop on physical, social and psychological levels (Brown \& Brown, 1996; Malina \& Bouchard, 1991; see Ellis, 2001).

The aim of the research was to determine interests and aspirations for sports of deaf and hard-of-hearing students. 


\section{METHODS}

\section{Sample respondents}

The sample consisted of 94 respondents, divided into two groups. The first group consisted of 47 deaf and hard-of-hearing students (30 deaf and 17 hard-ofhearing students), attending special educational institutions, and the other, the controlling group, consisted of that much of their peers from regular schools, both genders, average age of $16 \pm 1.27$ years.

\section{Measuring instrument}

In this research Test for examining interests and aspirations of students (IF, Suzic, 2003) was conducted. Test estimates students' perception of interests and aspirations for activities: studying, sports, music, TV, entertainment, reading - writing, love and dating and social work. In this study, attitudes to the activity of variable sport were assessed. Test is comprised of 20 statements - attitudes indicators, where ten statements relate to involvement in aforementioned activity and the other ten relate to perceived possibilities and opportunities that would be the consequence of this activity. Respondents had 6 offered responses: $0=\mathrm{I}$ do not know, $1=$ never, $2=$ sometimes, partly, $3=$ often, $4=$ mostly and $5=$ always. Results of the questionnaire were summed and total value was acquired as statistical array for processing and interpretation of the results. Results could range from 0 to 50 points. After summing, the total points were divided into 10 classes for data processing.

\section{Data analysis}

The data were processed in the SPSS for Windows program. Descriptive analysis was conducted, frequencies and percentages were calculated, and differences between the groups were tested with the t-test.

\section{RESULTS AND DISCUSSION}

Distribution of frequencies and percentages of responses show that deaf and hard-of-hearing students for the individual claims related to involvement in sport, most often chose the answer "always". However, this percentage of responses ranged from only $21.3 \%$ to $44.7 \%$. Respondents responded more favorably to claims related to the opportunities provided by sports, so the percentage of responses "always" ranged from $40.4 \%$ to $66.0 \%$.

Table 1. Distribution of the responses on involvement in sports and the opportunities provided by sports - deaf and hard-of-hearing students

\begin{tabular}{|c|c|c|c|c|c|c|}
\hline & I do not know & Never & Sometimes & Frequently & Mostly & Always \\
\hline Involvement in sports & $f(\%)$ & $f(\%)$ & $\mathrm{f}(\%)$ & $\mathrm{f}(\%)$ & $f(\%)$ & $f(\%)$ \\
\hline 1. I spend my time playing sports. & $2(2.2)$ & $7(14.9)$ & $12(25,5)$ & $6(12.8)$ & $10(21.3)$ & $10(21.3)$ \\
\hline 2. I am active in sports. & $3(6.4)$ & $7(14.9)$ & $12(25.5)$ & $3(6.4)$ & $11(23.4)$ & $11(23.4)$ \\
\hline 3. I achieve a lot in sports. & $2(4.3)$ & $11(23.4)$ & $11(23.4)$ & $5(10.6)$ & $8(17.0)$ & $10(21.3)$ \\
\hline 4. Whenever I can do it, I play sports. & $2(4.3)$ & $10(21.3)$ & $10(21.3)$ & $6(12.8)$ & $6(12.8)$ & $13(27.7)$ \\
\hline 5. I like to talk about sports. & $4(8.5)$ & $8(17.0)$ & $10(21.3)$ & $6(12.8)$ & $5(10.6)$ & $14(29.8)$ \\
\hline 6. It's important for me to be good at sports. & $2(4.3)$ & $7(14.9)$ & $11(23.4)$ & $7(14.9)$ & $4(8.5)$ & $16(34.0)$ \\
\hline 7. I appreciate people who are successful in sports. & $0(.0)$ & $8(17.0)$ & $(8.5)$ & $6(12.8)$ & $7(14.9)$ & $22(46.8)$ \\
\hline 8. I'm satisfied when doing sports. & $1(2.1)$ & $8(17.0)$ & $4(8.5)$ & $8(17.0)$ & $6(12.8)$ & $20(42.6)$ \\
\hline 9. I would like to have time for sports. & $2(4.3)$ & $8(17.0)$ & $3(6.4)$ & $7(14.9)$ & $8(17.0)$ & $19(40.4)$ \\
\hline $\begin{array}{l}\text { 10. I'm happy when I'm dealing with something that } \\
\text { relates to sports. }\end{array}$ & $3(6.4)$ & $7(14.9)$ & $3(6.4)$ & $7(14.9)$ & $6(12.8)$ & 21(44.7) \\
\hline Opportunities provided by sports & $f(\%)$ & $f(\%)$ & $f(\%)$ & $f(\%)$ & $f(\%)$ & $\mathrm{f}(\%)$ \\
\hline 11. To show your skills & $1(2.1)$ & $4(8.5)$ & $7(14.9)$ & $5(10.6)$ & $9(19.1)$ & $21(44.7)$ \\
\hline 12. To progress & $1(2.1)$ & $7(14.9)$ & $4(8.5)$ & $4(8.5)$ & $7(14.9)$ & $24(51.1)$ \\
\hline 13. To act independently & $2(4.3)$ & $6(12.8)$ & $3(6.4)$ & $6(12.8)$ & $7(14.9)$ & $23(48.9)$ \\
\hline 14. To achieve a high standard of living & $1(2.1)$ & $8(17.0)$ & $4(8.5)$ & $4(8.5)$ & $6(12.8)$ & $24(51.1)$ \\
\hline 15. You live your own way & $2(4.3)$ & $5(10.6)$ & $5(10.6)$ & $1(2.1)$ & $8(17.0)$ & $25(55.3)$ \\
\hline 16. To develop yourself as a person & $3(6.4)$ & $5(10.6)$ & $5(10.6)$ & $3(6.4)$ & $6(12.8)$ & $25(53.2)$ \\
\hline 17. To be physically active & $2(4.3)$ & $4(8.5)$ & $2(4.3)$ & $4(8.5)$ & $4(8.5)$ & $31(66.0)$ \\
\hline 18. For people to appreciate and respect you & $2(4.3)$ & $2(4.3)$ & $4(8.5)$ & $4(8.5)$ & $8(17.0)$ & $27(57.4)$ \\
\hline 19. To be together with other people & $3(6.4)$ & $3(6.4)$ & $2(4.3)$ & $7(14.9)$ & $6(12.8)$ & $26(55.3)$ \\
\hline 20. To participate equally in decision making & $2(4.3)$ & $6(12.8)$ & $2(4.3)$ & $8(17.0)$ & $10(21.3)$ & $19(40.4)$ \\
\hline
\end{tabular}


Distribution of frequencies and the percentage of responses show more favorable answers of the hearing students in relation to the answers of the deaf and hard-of-hearing students about their involvement in sports and the opportunities that it provides. For claims related to involvement in sports, hearing students were also most likely to opt for the "always" response, but this percentage of responses ranged from $29.3 \%$ to $66.0 \%$. For the claims related to the opportunities provided by sports percentage of responses "always" ranged from $46.8 \%$ to $59.6 \%$ (Table 2).

Table 2. Distribution of the responses on involvement in sports and the opportunities provided by sports - hearing students

\begin{tabular}{|c|c|c|c|c|c|c|}
\hline & I do not know & Never & Sometimes & Frequently & Mostly & Always \\
\hline Involvement in sports & $f(\%)$ & $f(\%)$ & $f(\%)$ & $f(\%)$ & $f(\%)$ & $f(\%)$ \\
\hline 1. I spend my time playing sports. & $0(.0)$ & $8(17.0)$ & $6(12.8)$ & $7(14.9)$ & $12(25.5)$ & $14(29.8)$ \\
\hline 2. I am active in sports. & $0(.0)$ & $8(17.0)$ & $6(12.8)$ & $9(19.1)$ & $8(17.0)$ & $16(34.0)$ \\
\hline 3. I achieve a lot in sports. & $0(.0)$ & $7(14.9)$ & $7(14.9)$ & $7(14.9)$ & $9(19.1)$ & $17(36.2)$ \\
\hline 4. Whenever I can do it, I play sports. & $0(.0)$ & $7(14.9)$ & $3(6.4)$ & $6(12.8)$ & $14(29.8)$ & $17(36.2)$ \\
\hline 5. I like to talk about sports. & $0(.0)$ & $6(12.8)$ & $5(10.6)$ & $5(10.6)$ & $9(19.1)$ & $22(46.8)$ \\
\hline 6. It's important for me to be good at sports. & $1(2.1)$ & $5(10.6)$ & $4(8.5)$ & $7(14.9)$ & $6(12.8)$ & $24(51.1)$ \\
\hline 7. I appreciate people who are successful in sports. & $0(.0)$ & $2(4.3)$ & $4(8.5)$ & $3(6.4)$ & $3(6.4)$ & $35(74.5)$ \\
\hline 8. I'm satisfied when doing sports. & $0(.0)$ & $3(6.4)$ & $4(8.5)$ & $5(10.6)$ & $9(19.1)$ & $26(55.3)$ \\
\hline 9. I would like to have time for sports. & $1(2.1)$ & $4(8.5)$ & $4(8.5)$ & $0(.0)$ & $7(14.9)$ & $31(66.0)$ \\
\hline $\begin{array}{l}\text { 10. I'm happy when I'm dealing with something tha } \\
\text { relates to sports. }\end{array}$ & $1(2.1)$ & $2(4.3)$ & $4(8.5)$ & $5(10.6)$ & $9(19.1)$ & $26(55.3)$ \\
\hline Opportunities provided by sports & $f(\%)$ & $\mathrm{f}(\%)$ & $\mathrm{f}(\%)$ & $f(\%)$ & $f(\%)$ & $f(\%)$ \\
\hline 11. To show your skills & $1(2.1)$ & $4(8.5)$ & $2(4.3)$ & $7(14.9)$ & $10(21.3)$ & $22(46.8)$ \\
\hline 12. To progress & $1(2.1)$ & $2(4.3)$ & $3(6.4)$ & $14(29.8)$ & $9(19.1)$ & $25(53.2)$ \\
\hline 13. To act independently & $2(4.3)$ & $2(4.3)$ & $2(4.3)$ & $7(14.9)$ & $11(23.4)$ & $23(48.9)$ \\
\hline 14. To achieve a high standard of living & $2(4.3)$ & $3(6.4)$ & $6(12.8)$ & $4(8.5)$ & $7(14.9)$ & $25(53.2)$ \\
\hline 15. You live your own way & $2(4.3)$ & $2(4.3)$ & $4(8.5)$ & $6(12.8)$ & $6(12.8)$ & $27(57.4)$ \\
\hline 16. To develop yourself as a person & $1(2.1)$ & $3(6.4)$ & $4(8.5)$ & $4(8.5)$ & $9(19.1)$ & $26(55.3)$ \\
\hline 17. To be physically active & $1(2.1)$ & $2(4.3)$ & $6(12.8)$ & $4(8.5)$ & $5(10.6)$ & $29(61.7)$ \\
\hline 18. For people to appreciate and respect you & $1(2.1)$ & $5(10.6)$ & $4(8.5)$ & $1(2.1)$ & $8(17.0)$ & $28(59.6)$ \\
\hline 19. To be together with other people & $1(2.1)$ & $4(8.5)$ & $6(12.8)$ & $4(8.5)$ & $5(10.6)$ & $27(57.4)$ \\
\hline 20. To participate equally in decision making & $1(2.1)$ & $2(4.3)$ & $5(10.6)$ & $7(14.9)$ & $7(14.9)$ & $25(53.2)$ \\
\hline
\end{tabular}

After summing the answers and comparing the results, it can be noticed that within the involvement in Sport, $46.8 \%$ of the deaf and hard-of-hearing students had a total of 36 to 50 points, that is, the claims were largely opposed by the answers "mostly" and "always" while the percentage of hearing students was significantly higher, i.e. 66\%. For the opportunities provided by sports, both groups expressed themselves similarly, so that $72.5 \%$ of deaf and hard-of-hearing students and $70.2 \%$ of those who can hear had 36 to 50 points.

The t-test also found a statistically significant difference in attitudes among the deaf / hard-of-hearing and hearing students when it comes to involvement in sports $(\mathrm{t}=-2.47 ; \mathrm{p}=.02)$, while there were no statistically significant differences among the groups on the opportunities provided by sports $(t=-.68 ; p=.50)($ Table 3$)$. 
Table 3. A comparative overview of the respondents' responses to involvement in sports and the opportunities provided by sports

\begin{tabular}{|c|c|c|c|c|c|c|c|c|}
\hline \multirow{3}{*}{ Points } & \multicolumn{4}{|c|}{ Involvement } & \multicolumn{4}{|c|}{ Opportunities } \\
\hline & \multicolumn{2}{|c|}{$\begin{array}{c}\text { Deaf/hard-of-hearing } \\
\text { students }\end{array}$} & \multicolumn{2}{|c|}{ Hearing students } & \multicolumn{2}{|c|}{$\begin{array}{c}\text { Deaf/hard-of-hearing } \\
\text { students }\end{array}$} & \multicolumn{2}{|c|}{ Hearing students } \\
\hline & $\mathrm{f}$ & $\%$ & $f$ & $\%$ & $f$ & $\%$ & $f$ & $\%$ \\
\hline$\leq 5$ & 0 & .0 & 0 & .0 & 0 & .0 & 1 & 2.1 \\
\hline $6-10$ & 5 & 10.6 & 1 & 2.1 & 4 & 8.5 & 1 & 2.1 \\
\hline $11-15$ & 2 & 4.2 & 1 & 2.1 & 1 & 2.1 & 1 & 2.1 \\
\hline $16-20$ & 6 & 12.7 & 3 & 6.3 & 4 & 8.5 & 1 & 2.1 \\
\hline $21-25$ & 7 & 15.0 & 1 & 2.1 & 1 & 2.1 & 2 & 4.3 \\
\hline $26-30$ & 1 & 2.1 & 6 & 12.7 & 2 & 4.2 & 1 & 2.1 \\
\hline $31-35$ & 4 & 8.5 & 4 & 8.5 & 1 & $2 . .1$ & 7 & 15.0 \\
\hline $36-40$ & 7 & 14.9 & 6 & 12.7 & 8 & 17.1 & 7 & 15.0 \\
\hline $41-45$ & 2 & 4.2 & 11 & 23.5 & 7 & 15.0 & 5 & 10.6 \\
\hline $46-50$ & 13 & 27.7 & 14 & 29.8 & 19 & 40.4 & 21 & 44.6 \\
\hline Total & 47 & 100.0 & 47 & 100.0 & 47 & 100.0 & 47 & 100.0 \\
\hline & \multicolumn{2}{|c|}{$M($ Deaf $)=31.66$} & \multicolumn{2}{|c|}{$t=-2.47 ; \boldsymbol{p}=.02$} & $\begin{array}{l}M( \\
M(\end{array}$ & $\begin{array}{l}83 \\
39.62\end{array}$ & \multicolumn{2}{|c|}{$t=-.68 ; p=.50$} \\
\hline
\end{tabular}

Through sport, disabled develop physically, mentally and socially. It is a crucial element for their successful integration with community, as many research studies have shown (Eichstaedt \& Lavay 1992; see Karademir, 2015).

When considering the development of motor skills, children who are deaf have been found to fall behind their hearing peers. However, participation in sporting activities helps reduce that deficiency in motor skill development (Dummer et al., 1996; Hartman, Houwen, \& Visscher, 2011; see Ellis, Lieberman, \& Dummer, 2013).

New opportunities, fun, hanging out with their peers, improving their physical health and skills are all reasons why hearing impaired students participate in sporting activities, studies have shown (Andreff, 2001; see Zipporah, 2016).

According to research conducted at California University, Jambor and Elliott (2005; see Karademir, 2015), what helped strengthen deaf students' self-esteem was the acceptance of their disability and seeing themselves as a part of community.

Vuljanić (2015) conducted research on hearing impaired children in the Republic of Croatia on a sample of 272 students with no hearing impairments and 60 children with hearing impairment, aged 6 to 11, in order to determine how many children who are hearing impaired participate in sports, organized sports activities. She car- ried out an analysis of the motor efficiency of children with respect to the factor of hearing impairment and participation in sports. The obtained results showed that children with hearing impairment, compared to hearing children, are significantly less involved in sports activities, which is in line with the results of our work.

The importance of the involvement and motivation of students with hearing impairment in sports activities is indicated by a study by Juras (1971) on a population of 120 deaf people, aged 20-35, which has come to the conclusion that most deaf athletes have very successfully integrated themselves into hearing working collective, they had more expressed positive personality traits, they were positively adapted to the social position without a pronounced tendency of isolation, egocentricity, distrust to the environment, affective reaction and aggression, which is especially important because often, in professional comments, the consequences of deafness are stated to be the consequences in the mental and social plan with negative tendency in the mentioned personality traits.

The study conducted by Mwangi (2009; see Zipporah, 2016) on application and effects of special instructional methods in physical education among hearing impaired children in special units in public elementary schools in Nairobi County, Kenya showed that the special instructional methods increased children's involvement in sports. 
Mwangi advised the teachers to consider the fact that children with disabilities may refuse to participate in physical activities during the programme because they may believe that they will not be able to match with their peers.

Hartman, Houwen and Visscher (2011) conducted a study to examine motor performance in deaf elementary school children and its association with sports participation. The population studied included 42 deaf children whose hearing loss ranged from 80 to $120 \mathrm{~dB}$. Their motor skills were assessed with the Movement Assessment Battery for Children, and a questionnaire was used to determine their active involvement in organized sports. The deaf children had significantly more borderline and definite motor problems than the normative sample: $62 \%$ (manual dexterity), 52\% (ball skills), and 45\% (balance skills). Participation in organized sports was reported by $43 \%$ of the children; these children showed better performance on ball skills and dynamic balance. This study demonstrates the importance of improving deaf children's motor skill performance, which might contribute positively to their sports participation.

Salman and Naz (2012; see Zipporah, 2016) conducted a study in eight special schools in Karachi in Pakistan Asia. In the study they examined what motivated the students who suffer from hearing impairment to engage in sporting activities. The basis for the study was hypothesis that engagement in sporting activities improves physical and social rehabilitation for disabled people and makes them more aware of their self-respect, skills, determination, and competency. Factors, from physical, psychological to economic, impacted on the determination of hearing impaired students to indulge in sporting activities. The highest rated factors were those which related to personal delights and competitive needs.

\section{CONCLUSION}

The results of the insufficient involvement of deaf and hard-of-hearing students in very important areas for their development and progress, such as sports, as well as the results of the opportunities provided by sports, should be an indicator that, in addition to other specific ways of working with this population (e.g. ., rehabilitation of listening and speaking), it is necessary to pay much more attention to these activities. Students point out the existence of interests and aspirations for sports, and active participation in sports can be a significant support to the development of ad- equate communication and social skills and general development.

Also, it has been confirmed that there should not be environmental prejudice about the abilities of deaf and hard-of-hearing people, and they must not be reconciled with the fact that, due to hearing impairment, they are less physically active.

The role of teachers and family is very important in increasing involvement in almost all activities, and also in sport.

\section{REFERENCES}

Atherton, M., Turner, G. H., \& Russell, D. (2001). More than a match: The role of football in Britain's deaf community. Soccer \& Society, 2(3), 22-43. doi:10.1080/714004857

Arsic, R., Stankovic, V., \& Zrnzevic, N. (2015). An analysis of the results achieved by deaf male and female athletes from around the world in certain athletes disciplines. Research in Kinesiology, 43(1), 42-46. Retrieved from http://fsprm.mk/wp-content/uploads/2015/05/Pages-fromRIK-_1_2015_za-email-10.pdf

Dummer, G. M., Haubenstricker, J. L., \& Stewart, D. A. (1996). Motor skill performances of children who are deaf. Adapted physical activity quarterly, 13(4), 400-414. Retrieved from https://pdfs.semanticscholar.org/e035/59543b689ef4 a2ea43605c0471c7b9e044ca.pdf.

Ellis, M. K. (2001). Influences of parents and school on sports participation and fitness levels of deaf children. Palaestra, 17(1), 44-49.

Ellis, M. K., Lieberman, L. J., \& Dummer, G. M. (2013). Parent influences on physical activity participation and physical fitness of deaf children. Journal of deaf studies and deaf education, 19(2), 270-281. doi: 10.1093/deafed/ent033.

Hartman, E., Houwen, S., \& Visscher, C. (2011). Motor skill performance and sports participation in deaf elementary school children. Adapted Physical Activity Quarterly, 28(2), 132-145. Retrieved from https://pdfs.semanticscholar.org/4a44/4506890be4b3d4169fe00ed4667efd1 0c631.pdf

Hasanbegović, H., \& Sinanović, O. (2008). Procjena određenih psiholoških karakteristika kod gluhih osoba [Estimate of certain psychic characteristics at tested deaf people]. Acta Medica Saliniana, 37 (2), 127-131.

Johnson, L. (2014). The barriers encountered by Deaf people within the sporting environment (Doctoral dissertation, Cardiff Metropolitan University). Retrieved from https://repository.cardiffmet.ac.uk/bitstream/handle/10369/6138/JOHNSON_LLOYD_ST20005136.docx. pdf? sequence $=1 \&$ isAllowed $=$ n.

Juras, Z. (1971). Značenje fizičke kulture u procesu rehabilitacije osoba oštećena sluha s aspekta defektologa-surdologa [Significe of physical education in the process of rehabilitation of persons with disturbed hearding from the aspects of a defectologist - surdologist]. Defektologija, 7(2), 5965.

Karademir, T. (2015). Fear of negative evaluation of deaf athletes. The Anthropologist, 19(2), 517-523. doi: 10.1080/09720073.2015.11891686 
Olaosun, A. O., \& Ogundiran, O. (2013). Assistive Technology For Hearing and Speech Disorders. Journal of Biology, Agriculture and Healthcare, 3(17), 116-120. Retrieved from https://iiste.org/Journals/index.php/JBAH/article/ view/8963/9133

Radoman, V. (2003). Psihologija jezika i jezičkih poremećaja [Psychology of Language and Language Disorders]. Belgrade: Faculty of Special Education.

Rajendran, V., Roy, F. G., \& Jeevanantham, D. (2012). Postural control, motor skills, and health-related quality of life in children with hearing impairment: a systematic review. European Archives of Oto-Rhino-Laryngology, 269(4), 1063-1071. doi: 10.1007/s00405-011-1815-4

Shemesh, R. (2010). Hearing impairment: Definitions, assessment and Management, in Stone J. H., \& Blouin, M. (eds.), International Encyclopedia of Rehabilitation. Retrieved from http://cirrie.buffalo.edu/encyclopedia/en/article/272/.

Suzić, N. (2003). Vaspitni rad u odjeljenskoj zajednici (drugo, dopunjeno izdanje) [Educational work within class meetings]. Banja Luka: TTC.
Vuljanić, A. (2015). Analiza sudjelovanja djece s oštećenjem sluha u sportu $i$ vrednovanje motoričke efikasnosti djece s obzirom na oštećenje sluha i sudjelovanje u sportu [An analysis of participation in sport in hearing imparied children and evaluation of motor efficiency in children with regard to the hearing impairment and participation in sport]. Doctoral disertation, University of Zagreb, Faculty of Kinesiology. Retrieved from https://repozitorij.kif. unizg.hr/islandora/object/kif:383/preview.

Zipporah, M. M. (2016). Determinants of participation in sports among students with hearing impairment in secondary schools for the deaf in Kenya. Doctoral dissertation, Kenyatta University. Retrieved from http://ir-library.ku.ac. $\mathrm{ke} /$ bitstream/handle/123456789/17603/determinants $\% 20$ of $\% 20$ participation $\% 20 \mathrm{in} \% 20$ sports $\% 20$ among..... pdf? sequence $=1$. 